\title{
PEMBERIAN PUPUK KANDANG TERHADAP PERTUMBUHAN, PRODUKSI BIOMASA PADA BEBERAPA VARIETAS JAGUNG HIBRIDA (Zea Mays)
}

\author{
Muhammad Mukhtar, Sri Suryaningsih Djunu, I Wayan Gede Ari Widiantara \\ Animal Husbandry Departmen, Agriculture Faculty Gorontalo State Universty
}

\begin{abstract}
This research was aimed to determine the effect of beef fertilizer on growth and biomass production in some corn hybrid varieties (Zea mays). This research used completely randomized design factorial $6 \times 4$ with four replications. The first factor is the corn hybrid varieties were V1 (Bisi-2), V2 (Bisi-16), V3 (Bisi-222), V4 (Nk-212), V5 (Pertiwi-2), V6 (Pacific224), and the second factor was the level of beef fertilizer were P0 (0 ton/ha), P1 (20 ton/ha), P2 (30 tons/ha), P3 (40 tons/ha). The parameters measured were growth of plant height, the fresh water production and leaf blade percentage of corn hybrid varieties. The results showed that the variety and level of treatment of fertilizer was highly significant effected $(P<0,01)$ to the plant high, the fresh water production and leaf blade percentage corn hybrid varieties. Interaction factor were significant effected $(\mathrm{P}<0.05)$ to the fresh water production, whereas in the growth of plant high and leaf blade percentage did not effected $(\mathrm{P}<0.05)$. Each treatment was getting the best results in plant height at V2P3 $(224 \mathrm{~cm})$, fresh water production at V4P3 (5234 g/plot) and leaf blade percentage at V4P2 (35.35\%).
\end{abstract}

Keywords:: beeforganic fertilizer, corn hybrids

\section{PENDAHULUAN}

\section{Latar Belakang}

Hijauan pakan ternak adalah segala macam hijauan dari tumbuh-tumbuhan atau tanaman yang dapat dimakan oleh ternak tanpa mengganggu kesehatan ternak tersebut, serta dapat dimanfaatkan untuk proses pertumbuhan, produksi, dan reproduksi. Hijauan pakan ternak merupakan salah satu bahan pakan ternak yang sangat diperlukan dan besar manfaatnya bagi kehidupan ternak terutama ternak ruminansia. Hijauan merupakan pakan utama yang harus tersedia untuk memenuhi kebutuhan ternak ruminansia. Kebutuhan pokok konsumsi hijauan makanan ternak untuk setiap harinya 10\% dari bobot badan ternak (Sofyan, 2010).
Pada usaha peternakan sapi potong yang maju, pengembangan pakan ternak bisa dilakukan dengan penanaman jagung sebagai sumber pakan hijauan segar yang biasa disebut fodder crop, dimana tanaman jagung dipanen saat mencapai produksi biomas tinggi dan belum menghasilkan biji jagung (fase vegetatif). Pemanfaatan jagung sebagai sumber hijauan segar kerena jagung merupakan tanaman yang paling cepat dan potensial menghasilkan biomas pakan per satuan waktu dan luas. Selain itu, jagung mempunyai kandungan nutrisi dan tingkat kecernaan yang tinggi sehingga sangat baik langsung digunakan sebagai pakan hijauan segar. 
Kegiatan pemupukan memberikan hasil produksi dan produktivitas yang optimal tergantung pada beberapa faktor, diantaranya jenis dan takaran pupuk yang digunakan. Jenis dan takaran pupuk ini banyak digunakan untuk mengkaji tanggap/respon tanaman jagung terhadap tindakan pemupukan. Penggunaan pupuk kimia/anorganik, secara terus menurus dalam waktu lama pada tanah dapat berpengaruh buruk pada kualitas tanah. Disamping itu, penggunaan pupuk anorganik dosis tinggi mengakibatkan menurunnya produktivitas lahan, terjadinya pencemaran lingkungan melalui air, meningkatnya residu kimia pada tanah dan tanaman. Salah satu alternatif yang dapat dilakukan dalam meningkatkan produksi tanaman jagung yaitu dengan penggunaan pupuk organik yang kaya akan kandungan hara.

Pupuk organik bermanfaat bagi peningkatan produksi pertanian baik kualitas maupun kuantitas mengurangi pencemaran lingkungan dan meningkatkan kualitas lahan secara berkelanjutan. Penggunaan pupuk organik dalam jangka panjang dapat meningkatkan produktifitas lahan dan dapat mencegah degradasi lahan. Sumber bahan untuk pupuk organik sangat beraneka ragam, dengan karakteristik fisik dan kandungan kimia atau hara yang sangat beraneka ragam pula, sehingga pengaruh dari penggunaan pupuk organik terhadap lahan dan tanaman dapat bervariasi (Susanto, 2002).

Penggunaan biomas jagung sebagai pakan ternak ruminansia di Indonesia belum dilakukan oleh masyarakat peternak karena rata-rata masih mengharapkan jagung pipil dan yang diberikan kepada ternak hanyalah limbah jeraminya saja. Sehingga dibutuhkan suatu data tentang produksi biomas dan kecernaan hijauan jagung fase puncak produksi (fase vegetatif) sehingga memberikan informasi dan dapat menambah paradigma peternak dalam menggunakan biomas jagung sebagai hijauan pakan ternak ruminansia khususnya sapi potong.

Publish: Departmen Animal Husbandry, Gorontalo State University

\section{METODE PENELITIAN}

Penelitian ini dilaksanakan pada bulan Maret - Mei 2015 di lahan perkebunan Desa Tri Rukun, Kecamatan Wonosari, Kabupataen Boalemo, Provinsi Gorontalo. Bahan yang digunakan dalam penelitian ini adalah: 1) varietas jagung hibrida yakni: bisi-2, bisi-16, bisi-222, nk-212, pertiwi-2, dan pacific-224, 2) pupuk organik (pupuk kandang sapi). Rancangan penelitian yang digunakan adalah metode Rancangan Acak Lengkap (RAL) pola faktorial $6 \times 4$ dengan 4 ulangan sebagai berikut:

- Faktor A adalah varietas:

$\mathrm{V}_{1}=$ Bisi-2

$\mathrm{V}_{2}=$ Bisi -16

$\mathrm{V}_{3}=$ Bisi -222

$\mathrm{V}_{4}=\mathrm{NK}-212$,

$\mathrm{V}_{5}=$ Pertiwi-2,

$\mathrm{V}_{6}$ : Pacific-224

- Faktor B adalah pupuk kandang

$\mathrm{P}_{0}=$ Tanpa pupuk kandang

$\mathrm{P}_{1}=$ Pupuk kandang 20 ton/ha

$\mathrm{P}_{2}=$ Pupuk kandang 30 ton/ha

$\mathrm{P}_{3}=$ Pupuk kandang 40 ton/ha

Penelitian ini menggunakan jarak tanam $20 \mathrm{~cm} \times 25 \mathrm{~cm}$ dan umur pemotongan adalah 60 hari setelah tanam. Parameter yang diamati dalam penelitian ini adalah:1) Pertumbuhan tanaman yaitu tinggi tanaman; 2) Produksi biomas yaitu produksi segar dan persentase daun. Data yang diperoleh diolah dengan Analysis of Varian (Anova)

\section{HASIL DAN PEMBAHASAN Tinggi Tanaman}

Tinggi tanaman merupakan satu indikator tumbuhan mampu menyerap unsur hara dengan baik dan ketersediaan hara dalam tanah mencukupi untuk pertumbuhan tanaman. Pertumbuhan tinggi tanaman antar perlakuan umur 60 hari setelah tanam dapat dilihat pada table berikut: 
Tabel 1. Rata-rata tinggi tanaman umur $60 \mathrm{hst}$

\begin{tabular}{lcccc}
\hline \multirow{5}{*}{$\begin{array}{c}\text { Varietas } \\
\text { (A) }\end{array}$} & P0 & P1 & P2 & P3 \\
\cline { 2 - 5 } Bisi-2 & 193 & 210.75 & 221.5 & 220 \\
Bisi-16 & 196.5 & 205.25 & 215.5 & 224 \\
Bisi-222 & 195.75 & 213.25 & 222.25 & 219.75 \\
NK-212 & 191.25 & 201.25 & 217 & 214.75 \\
Pertiwi-2 & 186.75 & 198.5 & 219 & 220.75 \\
Pacific-224 & 192.25 & 206.25 & 210 & 213 \\
\hline Keterangan: Huruf yang berbeda mengidentifikasikan pengaruh beda \\
sangat nyata pada taraf 1\%
\end{tabular}

Rataan pertumbuhan tinggi tanaman umur 30, 45, 60 hari setelah tanam menunjukan tanaman yang diberi perlakuan P1, P2, P3 labih tinggi dibanding dengan perlakuan lainnya (tabel 1, hasil terbaik ada pada perlakuan V2P3 yakni $224 \mathrm{~cm}$ dibandingkan dengan varietas lainnya. Sedangkan tinggi tanaman terendah tanpa perlakuan pemupukan terdapat pada varietas Pertiwi-2 (V5P0) yakni 186,75 cm. Hasil analisis ragam terhadap tinggi tanaman hasil penelitian menunjukkan bahwa perlakuan varietas dan perlakuan level pemupukan berpengaruh sangat nyata $(\mathrm{P}<0,01)$. Hasil penelitian Bara dan Chozin (2009) Pemberian pupuk kandang berpengaruh nyata terhadap pertumbuhan tinggi tanaman jagung umur 9 minggu. sedangkan tanpa pemberian pupuk kandang memperlihatkan tinggi tanaman $112,75 \mathrm{~cm}$. Pengaruh perlakuan terhadap tinggi tanaman diduga erat kaitannya dengan dosis/level pupuk yang diberikan, dimana semakin tinggi level pupuk yang diberikan akan semakin banyak unsur hara yang dapat serap tanaman. Hasil data menunjukkan bahwa pertumbuhan vegetatif seperti tinggi tanaman yang dipupuk kandang menjadi lebih baik. Hal ini disebabkan karena pada pupuk kandang disamping mengandung unsur hara makro meskipun terbatas, juga mengandung unsur hara mikro yang dapat memperbaiki sifat fisik, biologi tanah dan sebagai unsur pemacu pertumbuhan vegetatif tanaman (Nugroho, dkk., 1999).

Darmawan dan Baharsyah (1983), menyatakan bahwa ketersediaan hara yang cukup dan seimbang akan mempengaruhi proses metabolisme pada jaringan tanaman. Proses metabolisme adalah pembentukan dan perombakan unsur-unsur hara dan senyawa organik dalam tanaman. Lebih lanjut Rinsema, (1986) menyatakan bahwa kekurangan unsur hara tertentu dalam tanaman dapat berakibat buruk dan bila berlebihan dapat merusak pertumbuhan tanaman itu sendiri. Kebutuhan unsur hara untuk pertumbuhan jagung diantaranya adalah nitrogen yang penting dalam meningkatkan pertumbuhan vegetatif tanaman (Lingga, 2003). Marschner, (1986) menyatakan bahwa tanaman kekurangan unsur nitrogen akan tumbuh lambat dan kerdil. Kekurangan unsur hara nitrogen berakibat terhambat pembentukan atau pertumbuhan bagian-bagian vegetatif seperti daun, batang, dan akar.

Kekurangan unsur hara nitrogen berakibat terhambat pembentukan atau pertumbuhan bagian-bagian vegetatif seperti daun, batang, dan akar. Hal ini sejalan dengan pernyataan Sutedjo (2002) dan Iskandar, (2003) yang menyatakan bahwa tanaman tidak akan memberikan hasil yang maksimal apabila unsur hara yang diperlukan tidak tersedia.

\section{Produksi Segar}

Produksi segar merupakan indikator paling penting dalam menilai produktivitas suatu tanaman. Produksi segar merupakan keseluruhan berat segar tanaman setelah dilakukan pemotongan, dalam hal ini pemotongan tanaman jagung dilakukan dengan jarak $10 \mathrm{~cm}$ dari permukaan tanah. Pemotongan dilakukan pada umur 60 hari setelah tanam. Pengaruh pemberian pupuk kandang terhadap produksi segar tanaman jagung dapat dilihat pada Tabel berikut. 
Tabel 2. Rataan produksi segar/plot tanaman jagung umur 60 HST

\begin{tabular}{|c|c|c|c|c|}
\hline \multicolumn{5}{|c|}{ Level Pupuk Kandang (B) } \\
\hline $\begin{array}{l}\text { Varietas } \\
\text { (A) }\end{array}$ & P0 & P1 & P2 & P3 \\
\hline V1 & $4381.00^{\mathrm{d}}$ & $4785.50^{c}$ & $5004.50^{\mathrm{a}}$ & $4853.50^{\mathrm{b}}$ \\
\hline V2 & $4400.50^{\mathrm{d}}$ & $4552.50^{c}$ & $4752.50^{\mathrm{b}}$ & $5104.50^{\mathrm{a}}$ \\
\hline V3 & $4200.00^{c}$ & $4714.00^{\mathrm{b}}$ & $4981.00^{\mathrm{a}}$ & $4879.50^{\mathrm{ab}}$ \\
\hline V4 & $4387.50^{c}$ & $4838.00^{\mathrm{b}}$ & $5157.00^{\mathrm{ab}}$ & $5234.00^{\mathrm{a}}$ \\
\hline V5 & $4119.00^{c}$ & $4337.50^{\mathrm{b}}$ & $4781.00^{\mathrm{ab}}$ & $4953.00^{a}$ \\
\hline V6 & $4407.50^{c}$ & $4651.50^{\mathrm{b}}$ & $4834.00^{\mathrm{ab}}$ & $5054.00^{\mathrm{a}}$ \\
\hline
\end{tabular}

Tabel 2 menunjukkan data rata-rata produksi segar tanaman jagung yang diberi pupuk kandang sapi (P1, P2 dan P3) memiliki produksi segar lebih tinggi dari tanaman jagung tanpa pemberian pupuk (P0). Rata-rata produksi segar tertinggi terdapat pada varietas NK-212 dengan level pemupukan 40 ton/ha (V4P3) yaitu sebanyak $5054 \mathrm{~g} /$ plot dan produksi segar terendah terdapat pada varietas Pertiwi-2 tanpa pemupukan (V5P0) yaitu sebanyak $4119 \mathrm{~g} /$ plot. Hasil analisis sidik ragam terhadap produksi segar hasil penelitian menunjukkan bahwa perlakuan varietas dan perlakuan level pemupukan berpengaruh sangat nyata $(\mathrm{P}<0,01)$.

Hasil penelitian sebelumnya yang dilakukan oleh Indrasari dan Syukur (2006), melaporkan bahwa pemberian pupuk kandang pada tanaman jagung menunjukkan bahwa produksi segar tanaman yang lebih tinggi dibanding tanpa penggunaan pupuk kandang. Adapun dosis 30 ton/ha mampu memberikan hasil terbaik hingga mencapai $78,15 \mathrm{~g} /$ pot, sedangkan tanpa pemberian pupuk kandang mencapai 46,60 g/ pot.

Wayah, dkk., (2013) juga melaporkan bahwa pemberian pupuk kandang sapi pada tanaman jagung berpengaruh nyata terhadap bobot segar tanaman, produksi segar tanaman menjadi lebih tinggi dibanding tanpa pemberian pupuk kandang sapi. Adapun dosis 49 ton/ha mampu memberikan produksi tertinggi mencapai 371,56 $\mathrm{g} /$ tan sedangkan tanpa pemberian pupuk kandang sapi mencapai 351,98g/tan.

Laju pertumbuhan tanaman adalah kemampuan tanaman menghasilkan berat segar per satuan luas lahan per satuan waktu. Laju pertumbuhan tanaman dapat diartikan bertambahnya berat dalam komunitas tanaman per satuan luas tanah dalam satuan waktu (Gardner, dkk. 1991). Nitrogen merupaka unsur hara utama yang diperlukan tanaman jagung dalam jumlah relatif besar. Apabila unsur $\mathrm{N}$ yang tersedia tinggi, klorofil yang terbentuk akan meningkat. Klorofil mempunyai fungsi esensial dalam proses fotosintesis yaitu berfungsi menyerap energi sinar matahari dan mentranslokasikan ke seluruh bagian tanaman. Peningkatan tinggi tanaman, jumlah daun dapat menyebabkan pembentukan biomassa tanaman meningkat sehingga menghasilkan berat kering tanaman yang tinggi (Handayunik, 2008).

\section{Persentase Daun}

Semakin tinggi persentase daun suatu tanaman maka semakin tinggi pula kandungan nutrisi yang terkandung di dalamnya. Hal tersebut disebabkan karena nutrisi tanaman lebih banyak terdapat pada daun dibanding batang. Pengaruh pemberian pupuk kandang terhadap persentase daun tanaman jagung dapat dilihat pada Tabel berikut.

\begin{tabular}{|c|c|c|c|c|}
\hline \multirow{2}{*}{ Varietas } & \multicolumn{4}{|c|}{$\%$ Daun } \\
\hline & P0 & P1 & P2 & P3 \\
\hline V1 & $30.27^{b}$ & $30.99 \mathrm{~b}$ & $31.43^{a}$ & $31.39 \mathrm{ab}$ \\
\hline V2 & $30.84^{c}$ & $32.22^{\mathrm{ab}}$ & $32.64^{a}$ & $31.65^{\mathrm{b}}$ \\
\hline V3 & $29.57^{b}$ & $31.62^{\mathrm{ab}}$ & $32.00^{a}$ & $31.70^{\mathrm{ab}}$ \\
\hline V4 & $30.94^{c}$ & $32.22^{b}$ & $35.35^{\mathrm{a}}$ & $35.16^{\mathrm{a}}$ \\
\hline V5 & $28.59^{b}$ & $29.69^{a b}$ & $30.44^{\mathrm{a}}$ & $30.62^{a}$ \\
\hline V6 & $30.23^{c}$ & $31.87^{b}$ & $33.61^{\mathrm{ab}}$ & $33.87^{a}$ \\
\hline
\end{tabular}


Tabel 3 menunjukkan rataan prosentase daun tertinggi antara perlakuan yang diberi pupuk kandang adalah P1,P2, dan P3 dibanding dengan P0. Rataan Prosentase daun jagung tertinggi pada varietas NK-224 dengan level pemupukan 30 ton/ha (V4P2) yaitu sebanyak $35,35 \%$ dan persentase daun terendah pada varietas Pertiwi-2 level pemupukan 0 ton/ha (V5P0) yaitu sebanyak $28,59 \%$. Hasil analisis sidik ragam terhadap persentase daun hasil penelitian menunjukka varietas, level pemupukan berpengaruh sangat nyata $(\mathrm{P}<0,01)$. Penggunaan pupuk kandang sapi meningkatkan kemampuan tanah untuk menyimpan air agar tidak cepat menguap atau evaporasi, dengan keberadaan air tersebut dapat membantu proses pelapukan mineral dan bahan organik tanah sehingga dapat dimanfaatkan langsung oleh tanaman, Selain itu air berfungsi sebagai media gerak akar untuk menyerap unsur hara dalam tanah, serta mendistribusikannya ke seluruh bagian organ tanaman (Sudarto, dkk., 2003). Pemberian pupuk kandang sapi dilaporkan meningkatkan populasi mikrobia tanah dan meningkatkan serapan $\mathrm{N}, \mathrm{P}$ dan $\mathrm{K}$ (Handayunik, 2008). Pendapat itu didukung oleh Sutedjo (2002), yang menyatakan bahwa nitrogen diperlukan untuk merangsang pertumbuhan vegetatif, memperbesar ukuran daun dan meningkatkan kandungan klorofil. Penelitian Wangiyana, dkk., (2010) pengaruh positif pemberian pupuk kandang strategi "stay green" dalam hal ini ditunjukkan oleh jumlah daun hijau yang lebih tinggi pada umur 63 hst seperti juga pada umur 84 hst. Kondisi ini bisa terjadi diduga karena adanya sumbangan $\mathrm{N}$ dari hasil mineralisasi pupuk kandang sapi pada pemberian pupuk organik ini dibanding tanpa pemberian, mengingat pada saat aplikasi, pupuk kandang sapi tersebut sudah dalam bentuk terdekomposisi. Selain itu, pemberian pupuk kandang sapi diduga dapat mempertahankan daun tetap hijau selama fase generatif.

\section{Interaksi Antar Faktor Varietas Jagung Dan Level Pupuk Kandang Sapi}

Interaksi antar faktor perlakuan yaitu varietas jagung dan level pupuk kandang sapi berpengaruh nyata terhadap produksi segar pada taraf $(\mathrm{P}<0,05)$. Sedangkan pada tinggi tanaman dan persentase daun tidak berpengaruh nyata $(\mathrm{P}>0,05)$. Penggunaan level pupuk kandang sapi hasil terbaik untuk varietas jagung hasil perlakuan yaitu terdapat pada pemberian level pupuk kandang sapi 30 ton/ha, dimana dapat menghasilkan tinggi tanaman, produksi segar dan persentase daun tertinggi dari semua perlakuan. Tidak menutup kemungkinan penggunaan level pupuk kandang sapi 40 ton/ha masih dapat dipergunakan karena masih ada beberapa varieetas jagung menunjukkan hasil terbaik dan sedikit lebih rendah dari pemupukan 30 ton/ha.

\section{KESIMPULAN}

Pemberian pupuk kandang dengan level yang berbeda pada tanaman jagung memberikan hasil tinggi tanaman yang berbeda dimana semakin tinggi level pemberian maka tinggi tanaman semakin meningkat. Pertumbuhan tinggi tanaman tertinggi pada varietas jagung hibrida Bisi-16 di umur 60 HST dan menghasilkan tinggi tanaman $224 \mathrm{~cm}$, Produksi biomas di umur 60 HST tertinggi terdapat pada varietas NK-212 serta sebanyak $5054 \mathrm{~g} /$ plot dan produksi segar terendah pada varietas Pertiwi-2 tanpa level. Interaksi antar faktor perlakuan yakni varietas jagung dan level pemupukan berpengaruh nyata terhadap produksi segar pada taraf $(\mathrm{P}<0,05)$. Sedangkan tinggi tanaman dan persentase daun tidak berpengaruh nyata $(\mathrm{P}>0,05)$. 


\section{DAFTAR PUSTAKA}

Bara, A. dan M. A. Chozin. 2009. Pengaruh Dosis Pupuk Kandang dan Frekuensi Pemberian Pupuk Urea Terhadap Pertumbuhan dan Produksi Jagung (Zea Mays L) di Lahan Kering. Makalah Seminar Departemen Agronomi dan Hortikultura. Institut Pertanian Bogor. Bagor.

Darmawan, J. dan J. Baharsyah. 1983. Dasardasar Fisiologi Tanaman. InstitutPertanian Bogor. Bogor. $88 \mathrm{hlm}$.

Gardner, F.P., R.B. Pearce dan R.L. Mitchell. 1991. Fisiologi Tanaman Budidaya. Universitas Indonesia-Press. Jakarta. $432 \mathrm{Hlm}$.

Handayunik, W. 2008. Pengaruh pemberian kompos limbah padat terhadap sifat fisik, kimia tanah dan pertumbuhan tanaman jagung (zea mays) serta Efisiensi terhadap pupuk urea pada entisol Wajakmalang. Skripsi Universitas Brawijaya. Malang

Indrasari, A. dan A. Syukur. 2006. Pengaruh Pemberian Pupuk Kandang dan Unsur Hara Mikro Terhadap Pertumbuhan Jagung Pada Ultisol yang Dikapur. Jurnal Ilmu Tanah dan Lingkungan vol 6 (2) (2006) p: 116-123

Iskandar, D. 2003. Pengaruh Dosis Pupuk N, P, $\mathrm{K}$ Terhadap Pertumbuhan dan Produksi Jagung Manis di Lahan Kering. Prosiding Seminar Teknologi untuk Negeri 2003, Vol. II, hal. 1 - 5 /HUMAS-BPPT/ANY

Marschner, H. 1986. Mineral Nutrition in Higher Plants. Academis Press. London. 430 hal.

Nugroho, A., N. Basuki dan M.A. Nasution, 1999. Pengaruh Pemberian Pupuk Kandang dan Kalium Terhadap
Kualitas Jagung Manis pada Lahan Kering. Habitat 10 (105). p. 33-38.

Rinsema. W. T. 1986. Pupuk, Cara Pemupukan (Terjemahan H. M. Saleh). Bharat Karya Aksara. Jakarta. 235 hlm.

Sofyan, A. 2010. Pedoman teknis perluasan areal kebun hijauan makanan ternak. Kementerian Pertanian. Jakarta.

Sudarto, M. Zairin, Awaludin H., dan A. Surahman, 2003. Pengaruh Jenis dan Dosis Pupuk Kandang terhadap Pertumbuhan dan Produksi Jagung Manis (Zea mays saccharata Sturt). Pastura (1): 2.

Susanto, R.. 2002. Penerapan pertanian organik pemasyarakatan, pengembangannya. Kanisius.Yogyakarta.

Sutedjo, M.M. 2002. Pupuk dan Cara Pemupukan. Rineka Cipta, Jakarta. 177 hlm.

Wayah, E., Sudiarso dan R. Soelistyono.2013. Pengaruh Pemberian Air dan Pupuk Kandang SapiTerhadap Pertumbuhan dan Hasil Tanaman Jagung Manis (Zea mays saccharata sturt l.). JurnalProduksi Tanaman: Fakultas Pertanian Universitas Brawijaya. Malang. 